\title{
Upaya Meningkatkan Aktivitas Dan Hasil Belajar Matematika Melalui Penerapan Model Pembelajaran Kooperatif Tipe Numbered Heads Together (NHT) di SMP Negeri 1 Banda Aceh
}

\author{
Agustina \\ SMP Negeri 1 Banda Aceh \\ Email : agustina.smp1@ gmail.com \\ Doi : 10.32672/jsa.v7i5.1516
}

\begin{abstract}
ABSTRAK
Penelitian ini bertujuan untuk meningkatkan aktivitas dan hasil belajar siswa pada mata pelajaran Matematika materi persamaan linear satu . Metode penelitian yang digunakan adalah penelitian tindakan kelas (PTK) yang terdiri atas dua siklus, setiap siklus terdiri dari tiga kali pertemuan, setiap pertemuan terdiri dari empat tahap yaitu perencanaan, pelaksanaan, observasi dan refleksi. Subyek penelitian adalah siswa kelas VII-1 SMP Negeri 1 Banda Aceh tahun pelajaran 2017/2018 pada semester ganjil (I) yang berjumlah 28 siswa. Analisis data menggunakan teknik analisis diskriptif komparatif dengan membandingkan kondisi awal dengan hasil-hasil yang dicapai pada setiap siklus, dan analisis deskriptif kualitatif hasil observasi dengan membandingkan hasil observasi dan refleksi pada siklus satu dan siklus dua. Dari hasil tersebut penulis dapat mengambil kesimpulan bahwa Model pembelajaran kooperatif tipe Numbered Heads Together (NHT) dapat meningkatkan aktivitas belajar dan hasil belajar siswa kelas VII-1 SMP NEGERI 1 Banda Aceh pada materi ajar PLSV.
\end{abstract}

\section{Kata Kunci : Interaktif, Hasil Belajar, Matematika}

\section{PENDAHULUAN}

Matematika sebagai salah satu pelajaran dalam kelompok IPA yang termasuk sarana berpikir ilmiah sangat diperlukan untuk menumbuh kembangkan kemampuan berpikir logis, sistematis, dan kritis dalam diri peserta didik untuk menunjang keberhasilan belajarnya dalam menempuh pendidikan yang lebih tinggi. Bahkan matematika sangat diperlukan oleh semua orang dalam kehidupan sehari-hari. Selama ini proses pembelajaran matematika di sekolah kebanyakan berpusat/terfokus pada guru, serta dalam pelaksanaannya guru memegang kendali, memainkan peran aktif, sedangkan siswa cenderung pasif dalam menerima informasi, pengetahuan dan keterampilan dari guru. Salah saatu materi ajar yang dirasakan masih cukup sulit dipahami siswa adalah persamaan linear satu variabel (PLSV) khususnya dalam penggunaan atau penentuan simbol yang digunakan sebagai variabel.

Belajar merupakan kegiatan bagi setiap orang. Pengetahuan keterampilan, kebiasaan, kegemaran dan sikap seseorang terbentuk, dimodifikasi dan berkembang disebabkan belajar. Menurut Slameto (dalam Hadis, 2006: 60) mengemukakan bahwa: "Belajar ialah suatu proses usaha yang dilakukan individu untuk memperoleh suatu 
perubahan perilaku yang baru secara keseluruhan, sebagai hasil dari pengalaman individu itu sendiri dalam interaksi individu dengan lingkungannya”. Menurut Surya (dalam Riduwan, 2004: 198) menjelaskan belajar adalah suatu proses yang dilakukan oleh individu untuk memperoleh suatu perubahan tingkah laku yang baru secara keseluruhan, sebagai hasil dari pengalaman individu itu sendiri dalam interaksi dalam lingkungannya. Menurut Howard (dalam Ahmadi dan widodo (2004: 127) memberikan definisi belajar yaitu Learning is the process by which behavior (in the broader sense) is orginated or changed through practice or training. Dari uraian dapat dikemukakan bahwa belajar adalah suatu proses di mana tingkah laku (dalam arti luas) ditimbulkan atau di ubah melalui praktek atau latihan.

Berdasarkan hasil observasi awal dan wawancara dengan guru mata pelajaran matematika di kelas VII-1 SMP Negeri 1 Banda Aceh diperoleh informasi bahwa nilai rata-rata hasil belajar matematika tahun ajaran 2017 /2018 pada semester ganjil hanya mencapai rata-rata 60, khusus materi PLSV hanya mencapai rata-rata 58 dan ini belum memenuhi standar ketuntasan belajar yang ditetapkan yaitu 62 (KKM). Siswa yang memperoleh nilai $\geq 62$ hanya $25 \%$ dan siswa yang memperoleh nilai $\leq 62$ sebanyak $75 \%$. Menurut guru yang bersangkutan, penyebab rendahnya hasil belajar matematika siswa adalah kurangnya keaktifan siswa saat mengikuti proses pembelajaran dan pada akhirnya mengakibatkan rendahnya pemahaman siswa terhadap mata pelajaran matematika.

Salah satu cara untuk membangkitkan aktivitas siswa dalam proses pembelajaran adalah dengan menggunakan cara/model yang tepat yakni pembelajaran dapat menjadikan siswa sebagai subjek yang berupaya menggali sendiri, memecahkan sendiri masalahmasalah dari suatu konsep yang dipelajari, sedangkan guru lebih banyak bertindak sebagai motivator dan fasilitator. Mariyana (2005:4) menyatakan bahwa pembelajaran akan sangat bergantung pada pemahaman guru tentang hakekat anak sebagai peserta atau sasaran belajar.

Dengan melihat fenomena tersebut, peneliti bersama guru bermaksud mengadakan kerjasama dalam upaya memberikan solusi dengan menerapkan model pembelajaran kooperatif tipe Numbered Heads Together (NHT) dalam menyelesaikan soal persamaan linear satu variabel. Ibrahim (2000:6) mengemukakkan bahwa pembelajaran yang menggunakan model kooperatif memiliki karakteristik yaitu : 1). Siswa berkerja dalam kelompok secara kooperatif untuk menuntaskan materi belajarnya; 2). Kelompok dibentuk dari siswa yang memiliki kemampuan tinggi, sedang dan rendah; 3). Bila mana mungkin anggota kelompok berasal dari ras, budaya, suku, jenis kelamin berbeda-beda; dan 4). Penghargaan lebih berorientasi pada kelompok ketimbang individu. Nurhadi (dalam Awaliyah, 2008:12-14) mengemukakan bahwa langkah-langkah model pembelajaran kooperatif tipe NHT sebagai pengganti pertanyaan seluruh kelas. langkah-langkah tersebut kemudian dikembangkan menjadi enam langkah sesuai dengan kebutuhan penelitian ini, enam langkah tersebut yaitu persiapan, pembentukan kelompok, diskusi masalah, memanggil nomor anggota, memberi kesimpulan dan memberi penghargaan.

Model pembelajaran ini sangat cocok diterapkan pada pembelajaran matematika karena dalam mempelajari matematika, tidak cukup hanya dengan mengetahui dan menghafalkan konsep-konsep matematika tetapi juga dibutuhkan suatu pemahaman serta 
Agustina

kemampuan menyelesaikan persoalan matematika dengan baik dan benar sehingga diharapkan dapat meningkatkan hasil belajar siswa. Hal ini sangat sesuai dengan yang diungkapkan oleh Ibrahim (2000:10) bahwa tujuan utama pembelajaran kooperatif dalam kegiatan mengajar adalah: 1) hasil belajar; 2) penerimaan terhadap keragaman dan 3) pengembangan keterampilan sosial. Melalui penerapan model pembelajaran kooperatif tipe NHT siswa akan terlibat aktif dalam proses belajar. Aktivitas belajar diartikan sebagai suatu kegiatan yang dilakukan oleh siswa dalam pelaksanaan proses pembelajaran, dimana siswa berkerja atau berperan aktif dalam pembelajaran, sehingga dengan demikian siswa tersebut memperoleh pengetahuan, pengalaman, pemahaman dan aspek-aspek lain tentang apa yang ia lakukan Hamalik (2003:172). Dengan demikian, setiap siswa akan mempunyai tingkat kemampuan yang relatif sama terhadap pelajaran matematika yang dipelajarinya dan pada gilirannya hasil belajar yang diperoleh akan lebih baik.

\section{METODE PENELITIAN}

Penelitian ini termasuk dalam penelitian tindakan kelas. Penelitian ini dilaksanakan pada semester ganjil tahun ajaran 2016/2017, pada tanggal 5 November s/d 25 November 2017 dikelas VII-1 SMP Negeri 1 Banda Aceh. Subyek penelitian tindakan kelas ini adalah siswa-siswi kelas VII-1 SMP Negeri 1 Banda Aceh sebanyak 28 orang yang terdiri dari 12 orang siswa laki-laki dan 16 orang siswa perempuan. Data dalam penelitian ini adalah data kuantitatif dan data kualitatif. Data kuantitatif diperoleh dari evaluasi hasil belajar siswa, sedang data kualitatif diperoleh dari lembar observasi dan hasil refleksi diri.

\section{HASIL PENELITIAN DAN PEMBAHASAN \\ Data Aktivitas Belajar siswa}

Data mengenai aktivitas siswa kelas VII-1 SMP Negeri 1 Banda Aceh selama pembelajaran dengan model pembelajaran kooperatif tipe NHT diambil dengan menggunakan lembar observasi dengan cara memberikan skor pada aspek aktivitas yang dilakukan oleh siswa sesuai dengan kriteria yang telah ditentukan. Data mengenai aktivitas siswa dalam proses belajar-mengajar dapat diuraikan berdasarkan siklus, berikut ini.

Tabel 1 Skor Aktivitas Siswa pada pertemuan 1 Siklus 1

\begin{tabular}{|c|c|c|c|c|c|c|c|}
\hline \multirow{2}{*}{ Aspek Yang Dinilai } & \multicolumn{7}{|c|}{ Kelompok } \\
\hline & 1 & 2 & 3 & 4 & 5 & 6 & 7 \\
\hline $\begin{array}{l}\text { 1. Siswa mendengarkan dan memperhatikan penjelasan } \\
\text { guru }\end{array}$ & 2 & 3 & 2 & 3 & 3 & 3 & 2 \\
\hline 2. Siswa selalu berada dalam kelompoknya & 1 & 3 & 2 & 3 & 3 & 3 & 3 \\
\hline 3. Siswa aktif dalam kelompoknya & 3 & 2 & 3 & 2 & 3 & 3 & 1 \\
\hline 4. Siswa yang merasa kaku berada dalamkelompoknya & 3 & 3 & 3 & 2 & 3 & 4 & 3 \\
\hline $\begin{array}{l}\text { 5. Siswa berdiskusi dengan teman kelompoknya dalam } \\
\text { menyelesaikan masalah dalam LKS }\end{array}$ & 2 & 3 & 2 & 2 & 2 & 2 & 3 \\
\hline $\begin{array}{l}\text { 6. Siswa mengalami kesulitan dalam menyelesaikan } \\
\text { masalah dalam LKS }\end{array}$ & 2 & 3 & 2 & 1 & 2 & 2 & 2 \\
\hline $\begin{array}{l}\text { 7. Siswa mengajukan pertanyaan kepada guru saat } \\
\text { mengalami kesulitan dalam menyelesaikan masalah } \\
\text { dalam LKS }\end{array}$ & 2 & 2 & 3 & 2 & 3 & 3 & 1 \\
\hline $\begin{array}{l}\text { 8. Ada rasa takut pada siswa ketika nomor anggotanya } \\
\text { terpanggil }\end{array}$ & 2 & 3 & 3 & 2 & 3 & 2 & 2 \\
\hline 9. Siswa mampu menjawab atau mempresentasekan hasil & 1 & 2 & 2 & 2 & 2 & 2 & 4 \\
\hline
\end{tabular}




\begin{tabular}{|l|c|c|c|c|c|c|c|}
\hline kerja kelompoknya di depan kelas & & & & & & \\
\hline $\begin{array}{l}\text { 10. Siswa membuat rangkuman tentang materi yang } \\
\text { dipelajari }\end{array}$ & 1 & 2 & 2 & 2 & 2 & 3 & 1 \\
\hline Rata-Rata Aktivitas Kelompok & 1,90 & 2,60 & 2,40 & 2,10 & 2,60 & 2,70 & 2,50 \\
\hline Kategori & Kurang & Cukup & Cukup & Cukup & Cukup & Cukup & Cukup \\
\hline
\end{tabular}

Berdasarkan tabel menunjukkan rata-rata aktivitas siswa pada pertemuan 1 siklus 1 tergolong rendah, dimana kelompok 1 mempunyai rata-rata 1,90; kelompok 2 sebesar 2,60; kelompok 3 sebesar 2,40; kelompok 4 sebesar 2,10; kelompok 5 sebesar 2,60; kelompok 6 sebesar 2,73 dan kelompok 7 sebesar 2,50. Dari data tersebut, dapat dikategorikan menjadi 2 kategori yakni kategori kurang seperti kelompok 1 dan kategori cukup seperti kelompok 2, kelompok 3, kelompok 5, kelompok 6, dan kelompok 7.

Tabel 2. Skor Aktivitas Siswa pada pertemuan 2 Siklus 1

\begin{tabular}{|c|c|c|c|c|c|c|c|}
\hline \multirow{2}{*}{ Aspek Yang Dinilai } & \multicolumn{7}{|c|}{ Kelompok } \\
\hline & 1 & 2 & 3 & 4 & 5 & 6 & 7 \\
\hline $\begin{array}{l}\text { 1. Siswa mendengarkan dan memperhatikan penjelasan } \\
\text { guru }\end{array}$ & 4 & 4 & 3 & 4 & 4 & 4 & 4 \\
\hline 2. Siswa selalu berada dalam kelompoknya & 4 & 4 & 3 & 4 & 3 & 4 & 4 \\
\hline 3. Siswa aktif dalam kelompoknya & 4 & 3 & 3 & 4 & 4 & 4 & 3 \\
\hline 4. Siswa yang merasa kaku berada dalamkelompoknya & 3 & 1 & 1 & 3 & 3 & 3 & 3 \\
\hline $\begin{array}{l}\text { 5. Siswa berdiskusi dengan teman kelompoknya dalam } \\
\text { menyelesaikan masalah dalam LKS }\end{array}$ & 4 & 3 & 2 & 4 & 4 & 4 & 3 \\
\hline $\begin{array}{l}\text { 6. Siswa mengalami kesulitan dalam menyelesaikan } \\
\text { masalah dalam LKS }\end{array}$ & 4 & 1 & 2 & 3 & 3 & 4 & 2 \\
\hline $\begin{array}{l}\text { 7. Siswa mengajukan pertanyaan kepada guru saat } \\
\text { mengalami kesulitan dalam menyelesaikan masalah } \\
\text { dalam LKS }\end{array}$ & 2 & 2 & 2 & 3 & 2 & 3 & 3 \\
\hline $\begin{array}{l}\text { 8. Ada rasa takut pada siswa ketika nomor anggotanya } \\
\text { terpanggil }\end{array}$ & 3 & 1 & 2 & 1 & 4 & 1 & 2 \\
\hline $\begin{array}{l}\text { 9. Siswa mampu menjawab atau mempresentasekan hasil } \\
\text { kerja kelompoknya di depan kelas }\end{array}$ & 4 & 3 & 4 & 4 & 4 & 4 & 3 \\
\hline $\begin{array}{l}\text { 10. Siswa membuat rangkuman tentang materi yang } \\
\text { dipelajari }\end{array}$ & 3 & 1 & 1 & 1 & 1 & 1 & 1 \\
\hline Rata-Rata Aktivitas Kelompok & 3,5 & 2,6 & 2,3 & 3,1 & 3,2 & 3,2 & 2,8 \\
\hline Kategori & Baik & Cukup & Cukup & Baik & Baik & Baik & Baik \\
\hline
\end{tabular}

Berdasarkan tabel menunjukkan rata-rata aktivitas siswa pada pertemuan 2 siklus 1 tergolong tinggi, dimana kelompok 1 mempunyai rata-rata 3,50; kelompok 2 sebesar 2,60; kelompok 3 sebesar 2,30; kelompok 4 sebesar 3,10; kelompok 5 sebesar 3,20; kelompok 6 sebesar 3,20 dan kelompok 7 sebesar 2,80. Dari data tersebut, dapat dikategorikan menjadi 2 kategori yakni kategori cukup seperti kelompok 2 dan kelompok 3 serta kategori baik seperti kelompok 1, kelompok 4, kelompok 5, kelompok 6, dan kelompok 7. Dari tabel tersebut dapat dilihat peningkatan aktivitas siklus I dari kategori kurang menjadi cukup dan kategori cukup menjadi baik.

Untuk mendapatkan gambaran rata-rata aktivitas belajar siswa pada siklus 2 dapat dilihat pada Tabel berikut.

Tabel 3 Skor Aktivitas Siswa pada pertemuan 1 Siklus 2 
Agustina

\begin{tabular}{|c|c|c|c|c|c|c|c|}
\hline \multirow{2}{*}{ Aspek Yang Dinilai } & \multicolumn{7}{|c|}{ Kelompok } \\
\hline & 1 & 2 & 3 & 4 & 5 & 6 & 7 \\
\hline 1. Siswa mendengarkan dan memperhatikan penjelasan guru & 3 & 3 & 4 & 4 & 3 & 3 & 3 \\
\hline 2. Siswa selalu berada dalam kelompoknya & 4 & 3 & 3 & 4 & 2 & 4 & 4 \\
\hline 3. Siswa aktif dalam kelompoknya & 4 & 3 & 4 & 4 & 3 & 4 & 3 \\
\hline 4. Siswa yang merasa kaku berada dalamkelompoknya & 2 & 2 & 2 & 1 & 2 & 1 & 1 \\
\hline $\begin{array}{lllll}\text { 5. } & \begin{array}{l}\text { Siswa berdiskusi dengan teman } \\
\text { menyelesaikan masalah dalam LKS }\end{array} & \text { kelompoknya } & \text { dalam } \\
\end{array}$ & 2 & 2 & 4 & 4 & 3 & 3 & 4 \\
\hline $\begin{array}{ll}\text { 6. Siswa mengalami kesulitan dalam menyelesaikan masalah } \\
\text { dalam LKS }\end{array}$ & 3 & 2 & 2 & 2 & 2 & 2 & 2 \\
\hline $\begin{array}{l}\text { 7. Siswa mengajukan pertanyaan kepada guru saat mengalami } \\
\text { kesulitan dalam menyelesaikan masalah dalam LKS }\end{array}$ & 2 & 3 & 2 & 2 & 3 & 2 & 2 \\
\hline 8. Ada rasa takut pada siswa ketika nomor anggotanya terpanggil & 3 & 2 & 2 & 1 & 1 & 1 & 1 \\
\hline $\begin{array}{l}\text { 9. Siswa mampu menjawab atau mempresentasekan hasil kerja } \\
\text { kelompoknya di depan kelas }\end{array}$ & 4 & 4 & 4 & 3 & 3 & 3 & 3 \\
\hline 10. Siswa membuat rangkuman tentang materi yang dipelajari & 3 & 3 & 4 & 2 & 2 & 2 & 2 \\
\hline Rata-Rata Aktivitas Kelompok & 3,0 & 2,7 & 3,1 & 2,7 & 2,4 & 2,5 & 2,5 \\
\hline Kategori & Baik & Cukup & Baik & Cukup & cukup & cukup & Cukup \\
\hline
\end{tabular}

Berdasarkan tabel menunjukkan rata-rata aktivitas siswa pada pertemuan 1 siklus 2 tergolong tinggi karena tidak ada aktivitas yang tergolong kurang, dimana kelompok 1 mempunyai rata-rata 3,00; kelompok 2 sebesar 2,70; kelompok 3 sebesar 3,10; kelompok 4 sebesar 2,70; kelompok 5 sebesar 2,40; kelompok 6 sebesar 2,50 dan kelompok 7 sebesar 2,50. Dari data tersebut, dapat dikategorikan menjadi 2 kategori yakni kategori cukup seperti kelompok 2, kelompok 4, kelompok 5,kelompok 6 dan kelompok 7 serta kategori baik seperti kelompok1 dan kelompok 3.

Tabel 4. Skor Aktivitas Siswa pada pertemuan 2 Siklus 2

\begin{tabular}{|c|c|c|c|c|c|c|c|}
\hline & \multicolumn{7}{|c|}{ Kelompok } \\
\hline & 1 & 2 & 3 & 4 & 5 & 6 & 7 \\
\hline memperhatikan penjelasan guru & 3 & 4 & 4 & 4 & 4 & 4 & 4 \\
\hline 2. Siswa selalu berada dalam kelompoknya & 3 & 4 & 3 & 4 & 4 & 3 & 4 \\
\hline 3. Siswa aktif dalam kelompoknya & 4 & 4 & 4 & 4 & 4 & 4 & 4 \\
\hline 4. Siswa yang merasa kaku berada dalamkelompoknya & 2 & 1 & 3 & 3 & 1 & 3 & 4 \\
\hline $\begin{array}{l}\text { 5. Siswa berdiskusi dengan teman kelompoknya } \\
\text { menyelesaikan masalah dalam LKS }\end{array}$ & 4 & 4 & 4 & 4 & 4 & 4 & 4 \\
\hline $\begin{array}{l}\text { 6. Siswa mengalami kesulitan dalam menyelesaikan masalah dalam } \\
\text { LKS }\end{array}$ & 2 & 2 & 4 & 3 & 2 & 3 & 3 \\
\hline $\begin{array}{l}\text { 7. Siswa mengajukan pertanyaan kepada guru saat mengalami } \\
\text { kesulitan dalam menyelesaikan masalah dalam LKS }\end{array}$ & 1 & 4 & 3 & 3 & 4 & 2 & 4 \\
\hline 8. Ada rasa takut pada siswa ketika nomor anggotanya terpanggil & 1 & 1 & 1 & 1 & 4 & 4 & 4 \\
\hline $\begin{array}{l}\text { 9. Siswa mampu menjawab atau mempresentasekan hasil kerja } \\
\text { kelompoknya di depan kelas }\end{array}$ & 2 & 3 & 4 & 1 & 1 & 4 & 4 \\
\hline 10. Siswa membuat rangkuman tentang materi yang dipelajari & 4 & 4 & 1 & 4 & 3 & 1 & 4 \\
\hline Rata-Rata Aktivitas Kelompok & 2,60 & 3,10 & 3,20 & 3,10 & 3,10 & 3,20 & 3,90 \\
\hline Kategori & Cukup & Baik & Baik & Baik & Baik & Baik & Baik \\
\hline
\end{tabular}

Berdasarkan tabel di atas, menunjukkan rata-rata aktivitas siswa mengalami peningkatan, yang terlihat dari rata-rata aktivitas siswa setiap kelompok, dimana kelompok 1 sebesar 2,60; kelompok 2 sebesar 3,10; kelompok 3 sebesar 3,20; kelompok 4 sebesar 3,10; kelompok 5 sebesar 3,10; kelompok 6 sebesar 3,20 dan kelompok 7 sebesar 3,90. Dari data tersebut, dapat dikategorikan menjadi 2 kategori yakni kategori cukup seperti kelompok 1 dan kelompok 7 dan kategori baik seperti kelompok 2, kelompok 3, kelompok 4, kelompok 5, kelompok 6 dan kelompok 7.

Untuk melihat distribusi rata-rata aktivitas siswa pada setiap siklus, dapat dilihat pada tabel dibawah ini. 
Tabel 5. Distribusi rata-rata aktivitas siswa pada setiap siklus.

\begin{tabular}{|c|c|c|c|c|}
\hline \multirow{2}{*}{ Aspek Yang Dinilai } & \multicolumn{4}{|c|}{ Siklus } \\
\hline & I & Kategori & II & Kategori \\
\hline $\begin{array}{l}\text { 1. siswa mendengarkan dan memperhatikan penjelasan } \\
\text { guru }\end{array}$ & 3,86 & Baik & 3,86 & Baik \\
\hline 2. siswa selalu berada dalam kelompoknya & 3,71 & Baik & 3,57 & Baik \\
\hline 3. siswa aktif dalam kelompoknya & 3,57 & Baik & 4,00 & Sangat baik \\
\hline 4. siswa yang merasa kaku berada dalam kelompoknya & 2,43 & Cukup & 2,43 & Cukup \\
\hline $\begin{array}{l}\text { 5. siswa berdiskusi dengan teman kelompoknya dalam } \\
\text { menyelesaikan masalah dalam LKS }\end{array}$ & 3,43 & Baik & 4,00 & Sangat baik \\
\hline $\begin{array}{l}\text { 6. siswa mengalami kesulitan dalam menyelesaikan } \\
\text { masalah dalam LKS }\end{array}$ & 2,71 & Cukup & 2,71 & Cukup \\
\hline $\begin{array}{l}\text { 7. siswa mengajukan pertanyaan kepada guru saat } \\
\text { mengalami kesulitan dalam menyelesaikan masalah } \\
\text { dalam LKS }\end{array}$ & 2,43 & Cukup & 3,00 & Baik \\
\hline $\begin{array}{l}\text { 8. ada rasa takut pada siswa ketika nomor anggotanya } \\
\text { terpanggil }\end{array}$ & 2,00 & Kurang & 2,29 & Cukup \\
\hline $\begin{array}{l}\text { 9. siswa mampu menjawab atau mempresentasekan } \\
\text { hasil kerja kelompoknya di depan kelas }\end{array}$ & 3,71 & Baik & 2,71 & Cukup \\
\hline $\begin{array}{l}\text { 10. siswa membuat rangkuman tentang materi yang } \\
\text { dipelajari }\end{array}$ & 1,29 & Kurang & 3,00 & Baik \\
\hline Rata-Rata Aktivitas Siswa & 2,91 & & 3,16 & \\
\hline Kategori & Cukup & & Baik & \\
\hline
\end{tabular}

Berdasarkan tabel di atas, menunjukkan rata-rata skor persatuan aktivitas siswa persiklus cenderung mengalami peningkatan ke arah yang lebih baik, dimana pada siklus 1 rata-rata skor persatuan aktivitas siswa umumnya berada pada kategori cukup, sedangkan pada siklus 2 rata-rata skor persatuan aktivitas siswa umumnya berada pada kategori baik, dengan rata-rata aktivitas siswa pada siklus 1 sebesar 2,91 meningkat sebesar 0,25 pada siklus 2 atau meningkat menjadi 3,16. Selain itu juga, pada siklus 2 ini, ada beberapa aktivitas siswa yang berhasil ditingkatkan dari kategori kurang menjadi kategori baik diantaranya adalah membuat rangkuman tentang materi yang dipelajari dan ada rasa takut pada siswa ketika nomor anggotanya terpanggil. Selain itu juga penigkatan aktivitas sebesar 3,16 menyatakan bahwa dalam satu kelompok terdapat satu sampai dua siswa kurang mampi menerapkan semua satuan aktivitas yang dinilai, sedangkan 2,91 menyatakan bahwa dalam satu kelompok terdapat tiga sampai empat kurang mampu menerapkan semua satuan aktivitas yang dinilai.

Untuk mendapatkan gambaran rata-rata aktivitas siswa baik pada siklus 1 maupun siklus 2, dapat dilihat pada Gambar 1 berikut. 
Agustina

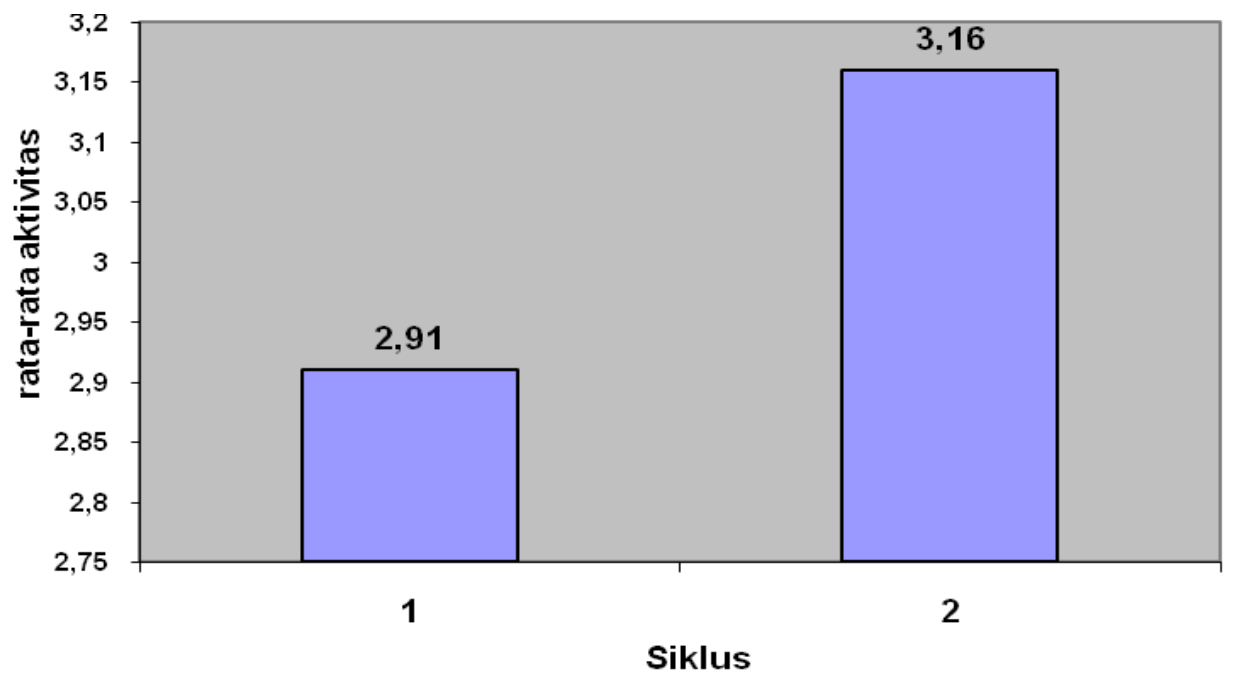

Gambar 1. Grafik Rata-Rata Aktivitas Siswa Setiap Siklus

Berdasarkan gambar 1 di atas, menunjukkan adanya peningkatan aktivitas siswa yang signifikan baik pada siklus 1 maupun siklus 2, dimana rata-rata aktivitas siswa pada siklus 1 sebesar 2,91 mengalami peningkatan sebesar 0,25 pada siklus 2 atau meningkat menjadi 3,16 .

\section{Data Aktivitas Guru selama KBM Berlangsung}

Untuk mendapatkan gambaran aktivitas guru dalam mengelola pembelajaran dengan menggunakan model pembelajaran NHT pada materi ajar Persamaan Linear Satu Variabel dapat dilihat pada tabel berikut.

Tabel 6. Skor Aktivitas Guru pada pertemuan 1 Siklus 1

\begin{tabular}{|c|c|}
\hline Aspek Yang Diamati Selama KBM & Penilaian \\
\hline 1. Memberitahu siswa tentang pendekatan pembelajaran yang digunakan & 3 \\
\hline 2. memotivasi siswa untuk belajar & 1 \\
\hline 3. menyampaikan tujuan/indikator yang harus dicapai dalam proses pembelajaran & 1 \\
\hline 4. memberi apersepsi kepada siswa sebelum memasuki materi pembelajaran & 2 \\
\hline 5. mengorganisasi siswa dalam kelompok & 4 \\
\hline 6. menyiapkan LKS untuk siswa & 4 \\
\hline 7. menjelaskan cara kerja dalam LKS kepada siswa & 3 \\
\hline 8. meminta siswa secara berkelompok menyelesaikan masalah dalam LKS & 4 \\
\hline 9. membimbing siswa dalam setiap kelompok menyelesaikan masalah dalam LKS & 4 \\
\hline 10. mengamati siswa bekerja dalam kelompoknya & 3 \\
\hline $\begin{array}{l}\text { 11. memanggil nomor anggota siswa dalam kelompok untuk menjawab atau } \\
\text { mempresentasekan hasil kerja kelompoknya }\end{array}$ & 4 \\
\hline 12. memberikan penghargaan kepadakelompok yang memperoleh hasil terbaik & 1 \\
\hline 13. mengarahkan siswa kejawaban yang benar & 3 \\
\hline 14. menyuruh siswa membuat rangkuman & 1 \\
\hline Rata-Rata Aktivitas Guru & 2,71 \\
\hline Kategori & Cukup \\
\hline
\end{tabular}

Berdasarkan tabel di atas, menunjukkan rata-rata aktivitas guru dalam mengelola pembelajaran pada siklus 1 tergolong rendah, dimana ada beberapa aspek pembelajaran NHT yang kurang diperhatikan guru untuk dilaksanakan seperti memotivasi siswa untuk 
belajar, menyampaikan tujuan/indikator yang harus dicapai dalam proses pembelajaran, memberikan penghargaan kepada kelompok yang memperoleh hasil terbaik, dan menyuruh siswa membuat rangkuman. Rata-rata aktivitas guru pada pertemuan 1 siklus 1 adalah 2,71 yang berkategori cukup.

Tabel 7. Skor Aktivitas Guru pada pertemuan 2 Siklus 1

\begin{tabular}{|ll|c|}
\hline \multicolumn{2}{|c|}{ Aspek Yang Diamati Selama KBM } & Penilaian \\
\hline 1. & Memberitahu siswa tentang pendekatan pembelajaran yang digunakan & 3 \\
\hline 2. & memotivasi siswa untuk belajar & 3 \\
\hline 3. & menyampaikan tujuan/indikator yang harus dicapai dalam proses pembelajaran & 4 \\
\hline 4. memberi apersepsi kepada siswa sebelum memasuki materi pembelajaran & 2 \\
\hline 5. mengorganisasi siswa dalam kelompok & 3 \\
\hline 6. menyiapkan LKS untuk siswa & 4 \\
\hline 7. menjelaskan cara kerja dalam LKS kepada siswa & 4 \\
\hline 8. meminta siswa secara berkelompok menyelesaikan masalah dalam LKS & 4 \\
\hline 9. membimbing siswa dalam setiap kelompok menyelesaikan masalah dalam LKS & 3 \\
\hline 10. & mengamati siswa bekerja dalam kelompoknya & 3 \\
\hline 11. memanggil nomor anggota siswa dalam kelompok untuk menjawab atau & 4 \\
\hline mempresentasekan hasil kerja kelompoknya & 2 \\
\hline 13. memberikan penghargaan kepadakelompok yang memperoleh hasil terbaik & 4 \\
\hline 14. mengarahkan siswa kejawaban yang benar & 1 \\
\hline \multicolumn{2}{|c|}{ Rata-Rata Aktivitas Guru } & 3,14 \\
\hline
\end{tabular}

Berdasarkan tabel di atas, rata-rata aktivitas guru dalam mengelola pembelajaran pada siklus 1 tergolong tinggi, dimana ada beberapa aspek pembelajaran NHT yang telah diperhatikan guru untuk dilaksanakan seperti memotivasi siswa belajar, menyampaikan tujuan/indikator yang harus dicapai dalam proses pembelajaran, memberikan penghargaan kepada kelompok yang memperoleh hasil terbaik. Rata-rata aktivitas guru pada pertemuan 2 siklus 1 adalah 3,14 yang berkategori cukup. Dalam hal ini untuk siklus 1 sudah mengalami sedikit peningkatan dari 2,71 meningkat sebesar 3,14 yang artinya ada beberapa aspek yang dinilai mengalami peningkatan seperti aspek 2, 3, dan 5 .

Untuk mendapatkan gambaran aktivitas guru dalam mengelola pembelajaran dengan menggunakan model pembelajaran NHT pada siklus 2 dapat dilihat pada tabel berikut.

Tabel 8. Skor Aktivitas Guru pada pertemuan 1 Siklus 2

\begin{tabular}{|c|l|c|}
\hline No & \multicolumn{1}{|c|}{ Aspek Yang Diamati Selama KBM } & Penilaian \\
\hline 1 & Memberitahu siswa tentang pendekatan pembelajaran yang digunakan & 3 \\
\hline 2 & memotivasi siswa untuk belajar & 3 \\
\hline 3 & menyampaikan tujuan/indikator yang harusdicapai dalam proses pembelajaran & 4 \\
\hline 4 & memberi apersepsi kepada siswa sebelum memasuki materi pembelajaran & 2 \\
\hline 5 & mengorganisasi siswa dalam kelompok & 3 \\
\hline 6 & menyiapkan LKS untuk siswa & 4 \\
\hline 7 & menjelaskan cara kerja dalam LKS kepada siswa & 4 \\
\hline 8 & meminta siswa secara berkelompok menyelesaikan masalah dalam LKS & 4 \\
\hline 9 & membimbing siswa dalam setiap kelompok menyelesaikan masalah dalam LKS & 3 \\
\hline 10 & mengamati siswa bekerja dalam kelompoknya & 3 \\
\hline 11 & memanggil nomor anggota siswa dalam kelompok untuk menjawab atau & 4 \\
\hline
\end{tabular}


Agustina

\begin{tabular}{|c|l|c|}
\hline & mempresentasekan hasil kerja kelompoknya & \\
\hline 12 & memberikan penghargaan kepadakelompok yang memperoleh hasil terbaik & 2 \\
\hline 13 & mengarahkan siswa kejawaban yang benar & 4 \\
\hline 14 & menyuruh siswa membuat rangkuman & 1 \\
\hline \multicolumn{2}{|c|}{ Rata-Rata Aktivitas Guru } & 3,14 \\
\hline Kategori & Baik \\
\hline
\end{tabular}

Tabel 9. Skor Aktivitas Guru pada pertemuan 2 Siklus 2

\begin{tabular}{|l|c|}
\hline \multicolumn{1}{|c|}{ Aspek Yang Diamati Selama KBM } & Penilaian \\
\hline 1. Memberitahu siswa tentang pendekatan pembelajaran yang digunakan & 3 \\
\hline 2. memotivasi siswa untuk belajar & 3 \\
\hline 3. menyampaikan tujuan/indikator yang harusdicapai dalam proses pembelajaran & 4 \\
\hline 4. memberi apersepsi kepada siswa sebelum memasuki materi pembelajaran & 2 \\
\hline 5. mengorganisasi siswa dalam kelompok & 4 \\
\hline 6. menyiapkan LKS untuk siswa & 4 \\
\hline 7. menjelaskan cara kerja dalam LKS kepada siswa & 4 \\
\hline 8. meminta siswa secara berkelompok menyelesaikan masalah dalam LKS & 4 \\
\hline 9. membimbing siswa dalam setiap kelompok menyelesaikan masalah dalam LKS & 4 \\
\hline 10. mengamati siswa bekerja dalam kelompoknya & 3 \\
\hline 11. memanggil nomor anggota siswa dalam kelompok untuk menjawab atau & 3 \\
\hline mempresentasekan hasil kerja kelompoknya & 3 \\
\hline 12. memberikan penghargaan kepadakelompok yang memperoleh hasil terbaik & 4 \\
\hline 14. mengarahkan siswa kejawaban yang benar & 2 \\
\hline \multicolumn{2}{|c|}{ Rata-Rata Aktivitas Guru } \\
\hline
\end{tabular}

Berdasarkan dari tabel 8 dan tabel 9 di atas, tampak bahwa aktivitas guru sudah menunjukkan peningkatan dari siklus 1 , dimana rata-rata aktivitas guru dalam mengelola pembelajaran pada siklus 2 adalah sebesar 3,36 yang berkategori baik. Hal ini menujukkan bahwa guru telah menerapkan model pembelajaran Kooperatif tipe NHT pada materi ajar persamaan linear satu variabel dengan baik, yang tercermin pada setiap fase pembelajaran seperti menyuruh siswa membuat rangkuman.

\section{Data Hasil Belajar Siswa}

Data mengenai hasil belajar Matematika siswa diambil dengan menggunakan tes (evaluasi) hasil belajar. Berdasarkan analisis deskriptif terhadap hasil belajar Matematika siswa pada materi ajar persamaan linear satu variabel, yang ditunjukkan dalam bentuk tes awal, tes siklus I, dan tes siklus II, diperoleh data sebagai berikut.

Tabel 10 Hasil Belajar Matematika Siswa pada Materi Ajar Persamaan

Llinear Satu Variabel

\begin{tabular}{|c|l|c|c|c|c|}
\hline No & \multicolumn{1}{|c|}{ Nama Siswa } & Kelompok & Tes Awal & Tes Siklus I & Tes Siklus II \\
\hline 1 & Adri Gosar & \multirow{4}{*}{ I } & 70 & 75 & 90 \\
\hline 2 & Anna Mustika hati & 60 & 65 & 80 \\
\hline \multirow{nnnnyy}{nnnnyy}{} & & 55 & 65 & 80 \\
\hline 4 & Ardiansyah & & 65 & 80 & 80 \\
\hline 5 & Ayu Aulia & \multirow{2}{*}{ II } & 70 & 80 & 80 \\
\hline 6 & & 55 & 75 & 90 \\
\hline
\end{tabular}




\begin{tabular}{|c|c|c|c|c|c|}
\hline 7 & Fera Asria & & 80 & 95 & 90 \\
\hline 8 & Genna Melinda & & 70 & 95 & 100 \\
\hline 9 & Gusty Pratama & \multirow{4}{*}{ III } & 65 & 55 & 65 \\
\hline 10 & Resky Paradilla & & 50 & 55 & 65 \\
\hline 11 & Julinar Dwi & & 60 & 95 & 100 \\
\hline 12 & LM. Ariffarqat & & 55 & 55 & 70 \\
\hline 13 & Mawar Marwati & \multirow{4}{*}{ IV } & 70 & 70 & 80 \\
\hline 14 & Muh. Falah Al-Mubarak & & 40 & 70 & 90 \\
\hline 15 & Muh. Yulianto & & 70 & 70 & 70 \\
\hline 16 & Nabila & & 70 & 75 & 70 \\
\hline 17 & Rachi Septiana & \multirow{4}{*}{$\mathrm{V}$} & 75 & 90 & 100 \\
\hline 18 & Rachmat Tata Pratama & & 35 & 40 & 50 \\
\hline 19 & Riska & & 75 & 95 & 90 \\
\hline 20 & Rusdi & & 50 & 55 & 50 \\
\hline 21 & Silvani Dongga & \multirow{4}{*}{ VI } & 60 & 70 & 80 \\
\hline 22 & Sitti Rahayu & & 80 & 95 & 100 \\
\hline 23 & Suci Putri Hawa & & 55 & 75 & 90 \\
\hline 24 & Wd. Nur azijah & & 55 & 95 & 90 \\
\hline 25 & Yoel Tiku Ali & \multirow{4}{*}{ VII } & 55 & 55 & 80 \\
\hline 26 & Yulya Lasmita & & 60 & 95 & 100 \\
\hline 27 & Fenri Heri & & 25 & 60 & 80 \\
\hline 28 & Andi Sultan & & 70 & 50 & 60 \\
\hline \multicolumn{3}{|c|}{ Jumlah } & 1700 & 2050 & 2270 \\
\hline \multicolumn{3}{|c|}{ Rata-rata } & 60,71 & 73,21 & 81,07 \\
\hline \multicolumn{3}{|c|}{ Ketuntasan Hasil Belajar secara klasikal } & $60,71 \%$ & $75,00 \%$ & $92,86 \%$ \\
\hline
\end{tabular}

Berdasarkan tabel 10 di atas, kita dapat melihat bahwa hasil belajar Matematika siswa kelas VII-1 SMP Negeri 1 Banda Aceh pada materi ajar PLSV setelah diajar dengan menerapkan model pembelajaran kooperatif tipe NHT menunjukkan adanya peningkatan baik dari tes awal maupun hasil belajar siswa pada setiap siklus, dimana ratarata hasil belajar siswa pada siklus 1 adalah sebesar 73,21 dan rata-rata hasil belajar siswa pada siklus 2 sebesar 81,07. Berdasarkan tabel 10 di atas, menunjukkan adanya peningkatan hasil belajar Matematika siswa yang signifikan baik dari tes awal maupun hasil belajar siswa pada setiap siklus, dimana rata-rata hasil belajar siswa pada siklus 1 adalah sebesar 73,21 dengan nilai maksimum 95 dan nilai minimum 40 dan rata-rata hasil belajar siswa pada siklus 2 meningkat sebesar 81,07 dengan nilai maksimum 100 dan nilai minimum 50. Demikian pula pada rata-rata tes awal siswa yaitu 60,71 dengan nilai maksimum 80 dan nilai minimum 25. Berdasarkan tabel 10 di atas, menunjukkan adanya peningkatan jumlah siswa (\%) yang sudah tuntas secara klasikal pada setiap siklus, dimana pada siklus 1 terdapat $75,00 \%$ siswa yang sudah tuntas sedangkan pada siklus 2 terdapat $92,86 \%$ siswa yang sudah tuntas.

\section{PENUTUP}

\section{Simpulan}

Berdasarkan hasil analisis dari beberapa siklus dan pembahasan, maka dapat disimpulkan bahwa: 
Agustina

1. Model pembelajaran kooperatif tipe Numbered Heads Together (NHT) dapat meningkatkan aktivitas belajar siswa kelas VII-1 SMP Negeri 1 Banda Aceh pada materi ajar PLSV. Hal ini tergambar dari rata-rata aktivitas siklus I mencapai 2,91 dan meningkat sebesar 3,16 oada siklus II.

2. Model pembelajaran kooperatif tipe Numbered Heads Together (NHT) dapat meningkatkan hasil belajar belajar siswa kelas VII-1 SMP Negeri 1 Banda Aceh pada materi ajar PLSV. Peningkatan hasil belajar diperoleh dari hasil tes tindakan setiap siklus, dimana siklus I mencapai 75,00\%, dan siklus II mencapai 92,86\%. Model pembelajaran kooperatif tipe Numbered Heads Together (NHT) sudah terlaksana sesuai dengan skenario pembelajaran di kelas VII-1 SMP Negeri 1 Banda Aceh. Keterlaksanaan dari siklus I mencapai rata-rata sebesar 75,00 \%, dan siklus II mencapai rata-rata sebesar $92,86 \%$.

\section{DAFTAR PUSTAKA}

Ahmadi, Abu dan Supriyono W. 2004. Psikologi Belajar. Rineka Cipta: Jakarta

Awaliyah, Hilda. 2008. Efektivitas Pendekatan Pembelajaran Kooperatif Model Numbered Head Together (NHT) Dalam Meningkatkan Hasil Belajar Matematika Siswa Kelas VII SMP Negeri 8 Kendari Pada Pokok Bahasan Persamaan Linear Satu Variabel (PLSV). Universitas Haluoleo. Kendari.

Hadis, Abdul. 2006. Psikologi Dalam Pendidikan. Alfabeta: Bandung.

Hamalik, Oemar. 2003. Proses Belajar Mengajar. PT. Bumi Aksara: Jakarta.

Ibrahim, M. dkk., 2000. Pembelajaran Kooperatif. Surabaya: Universitas Negeri Surabaya.

Mariyana, Rita. 2005. Strategi Pengelolaan Lingkungan Belajar Di Taman Kanak-Kanak. Departemen Pendidikan Nasional. Jakarta.

Riduwan. 2004. Belajar Mudah Penelitian Untuk Guru-Karyawan dan Peneliti Pemula. Alfabeta: Bandung. 